Jurnal Maenpo: Jurnal Pendidikan Jasmani kesehatan dan Rekreasi

Volume 11 Nomor 1 Tahun 2021

https://jurnal.unsur.ac.id/maenpo

This Work Is Licensed Under A Creative Commons Attribution-

Sharealike 4.0 International License @) (1) (-)

Original Article

\title{
The Research Of Students' Motor Ability In Archery Extracurricular
}

\author{
Arisman $^{1}$, Roby Agun Guntara ${ }^{2}$ \\ ${ }^{1,2}$ Pendidikan Kepelatihan Olahraga, Fakultas Keguruan dan Ilmu Pendidikan Universitas \\ Mitra Karya, Indonesia \\ arisman.900225@gmail.com ${ }^{1}$,agun0145@gmail.com ${ }^{2}$
}

\section{ABSTRAK}

Tujuan penelitian ini adalah untuk mengetahui Kemampuan Motorik siswa Ekstrakurikuler Panahan Sekolah Dasar Harapan Indonesia. Penelitian ini di latarbelakangi oleh rendahnya kemampuan gerak dasar siswa sehingga perlu dikaji lebih lanjut. Kemampuan tersebut sangat diperlukan bagi perkembangan siswa karena dengan semakin banyaknya siswa melakukan Gerak Multilateral. maka, Motorik para siswa juga akan semakin bagus. Hal tersebut sangat mempengaruhi Bakat yang dimiliki oleh setiap peserta didik dalam mencapai Prestasi khususnya di bidang Olahraga Panahan. Adapun Jenis penelitian yang dipakai yaitu Deskriptif dalam menggambarkan kondisi tertentu dengan jumlah sampel siswa laki-laki sebanyak 30 Responden. Teknik sampel diambil dengan purposive sampling, yaitu pengambilan sampelnya berdasarkan pertimbangan tertentu. Pelaksanaannya dilakukan di Sekolah Dasar Harapan Indonesia. Data diambil menggunakan Tes Kemampuan Motorik dengan rentangan 10-12 tahun. Teknik analisis datanya menggunakan cara Statistik Deskriptif. Hasil analisis menunjukkan kemampuan motorik siswa dari 30 responden di peroleh kategori "baik sekali" sebanyak 7 orang atau $23.33 \%$, kategori "baik" sebanyak 9 orang atau 30.00\%, kategori "sedang" sebanyak 12 orang atau $40.00 \%$, kategori "kurang" sebanyak 2 orang atau $6.67 \%$, sedangkan kategori "kurang sekali" tidak ada.

Kata kunci: Kemampuan Motorik, Ekstakurikuler, Panahan.

\section{ABSTRACT}

The purpose of this study was to determine the Motor Ability of Archery Extracurricular Students at Harapan Indonesia Elementary School. This research is motivated by the low basic movement ability of students so that it needs to be studied further. This ability is very necessary for the development of students because with the increasing number of students doing Multilateral Movement. then, the students' motor skills will also get better. This greatly affects the talents possessed by each student in achieving achievements, especially in the field of Archery. The type of research used is descriptive in describing certain conditions with a sample of 30 male students. The sampling technique was taken by purposive sampling, namely the sampling was based on certain considerations. The implementation was carried out at Harapan Indonesia Elementary School. Data were taken using Motor Ability Test with a range of 10-12 years. The data analysis technique uses descriptive statistics. The results of the analysis showed that the motor skills of 
14 | Arisman', Roby Agun Guntara ${ }^{2}$

The Research of Students' Motor Ability in Archery Extracurricular

students from 30 respondents were obtained in the "very good" category as many as 7 people or $23.33 \%$, the "good" category as many as 9 people or $30.00 \%$, the "moderate" category as many as 12 people or $40.00 \%$, the "less" category as many as 2 people or $6.67 \%$, while there is no "very little" category.

Key words: Motor Ability, Archery, Ektracurricular

Received:02-06-2021; Accepted:14-06-2021; Published:20-06-2021

(C) 2021 Universitas Suryakancana

ISSN: 2721-7175(online) p-ISSN: 2089-2341 (cetak)

\section{PENDAHULUAN}

Berolahraga bisa mengembangkan berbagai keterampilan dan kemampuan aktivitas gerak yang berhubungan dengan fisik siswa sehingga perkembangan dan pertumbuhan fisiknya menjadi lebih baik. Di samping itu bergerak juga dapat meningkatkan kesehatan sekaligus kebugaran jasmani serta mampu mengembangkan sikap fair play sehingga mampu bekerja sama dengan orang lain.Aktifitas dalam berolahraga harus dilakukan dengan menggunakan keterampilan gerak yang baik, disamping faktor latihan juga ada faktor lainnya yang mempengaruhi. diantaranya kemampuan motorik siswa, faktor ini akan mempengaruhi efektifitas siswa dalam melakukan gerak, Misalnya sewaktu siswa berlari, berjalan, melompat dan memanjat serta kejar-kejaran, hal ini merupakan motorik atau aktivitas gerak yang mereka lakukan sebagai upaya dalam memperkaya gerak multilateral dalam ruang dan waktu yang dapat diamati secara nyata sebagai pengalaman bagi siswa.

Kemampuan motorik dianggap bisa memudahkan pelaksanaan keterampilan gerak. Menurut (Sukintaka, 2004) disebutkan bahwa "mobilitas mengacu pada pergerakan dorongan internal berupa keterampilan yang lebih rendah untuk tujuan eksternal, dan bentuk gerakan memiliki gerakan ke luar yang dapat diamati, sehingga mengutamakan ketepatan" kemudian (Kiram, 2005) juga mengatakan bahwasanya motorik merupakan "peristiwa potensial, termasuk semua proses yang mengontrol dan mengatur organ secara fisik dan psikologis, yang berujung pada terjadinya suatu gerakan”. Selain itu, keterampilan motorik merupakan kualitas umum yang dapat ditingkatkan melalui berbagai latihan olahraga. Di sisi lain (Magill, 1980) 
mengemukakan "Gerakan merupakan pergeseran posisi yang terjadi secara terusmenerus dan bisa diamati secara eksternal, sedangkan motor adalah denyut yang terjadi secara terus menerus dan tidak dapat diamati secara internal". Kemudian (Gusril, 2008) menjelaskan "motorik (gerak) dapat dikatakan bahwa perubahan posisi dan kecepatan tubuh atau bagian tubuh manusia yang dapat diamati secara objektif terjadi dalam ruang dan waktu.

Kemampuan motorik ini merupakan faktor penentu keberhasilan anak dalam menguasai cabang olahraga nantinya, salah satunya olahraga panahan. Olahraga ini banyak diminati oleh kalangan anak usia dini, dikarenakan proses gerakannya berupa statis dan dinamis. Maka dari itu, Sekolah Dasar Harapan Nusantara mengadakan Kegiatan Ektrakurikuler diluar jam pelajaran agar siswa termotivasi dalam melakukan gerak.Ektrakurikuler memegang peranan penting bagi siswa disekolah untuk meningkatkan dan mengambangkan bakatnya. "Ekstrakurikuler merupakan sarana untuk menumbuhkan bakat dan minat siswa di waktu senggang" (Lestari, 2016). "Melalui kegiatan yang berbeda, siswa dapat dengan leluasa memilih jenis kegiatan yang disukainya. semuanya tergantung pada bakat, minat dan kemampuan masingmasing" (Awalia \& Prasetio, 2015)

Biasanya pengembangan bakat yang diadakan disekolah meliputi beberapa mata pelajaran yang dianggap sebagai pilihan utama menuju kompetisi antar sekolah begitu juga dengan kegiatan Olahraga, ada beberapa aneka ragam cabang olahraga seperti Sepakbola, Bolavoli, Bolabasket, Tenis Meja, Bulutangkis dan Beladiri. Semua Cabang tersebut sudah banyak diteliti. Maka dari itu, Novelty penelitian ini dilakukan lebih mengarah ke cabang Olahraga Panahan karena masih jarang dilakukan apalagi menelaah tentang kemampuan motorik siswa dalam mempelajari Olahraga tersebut.

\section{METODE}

Penelitian ini berjenis deskriptif dengan tujuan untuk mengungkapkan aslinya. Seperti yang dikatakan (Arikunto, 2002), "Penelitian deskriptif tidak dimaksudkan untuk menguji hipotesis tertentu, tetapi hanya mendeskripsikan penelitian yang 
berkaitan dengan variabel, gejala atau kondisi.". Adapun sampel yang diambil dalam penelitan ini sebanyak 30 Responden siswa putra kelas V dan Kelas VI, berikut diraikan pada tabel.

Tabel 1. Sampel Penelitian

\begin{tabular}{llll}
\hline No & Kelas & Sampel & Keterangan \\
\hline 1 & V & 17 & Putra \\
2 & VI & 13 & Putra \\
& Jumlah & 30 & \\
\hline
\end{tabular}

Sumber : SD Harapan Indonesia

Teknik dan Alat Pengumpulan Data

(Depdiknas, 2006) menjelaskan "tes kemampuan motorik diantaranya lari cepat selama 30 meter, sit up 30 detik, lari bolak-balik 4x10 meter, vertical jump".

Kekuatan (strength) diukur dengan cara berdiri tegak (vertical jumping) Tujuan dari tes ini adalah untuk mengetahui daya ledak otot tungkai. Lebih jelasnya, dijelaskan pada gambar berikut.
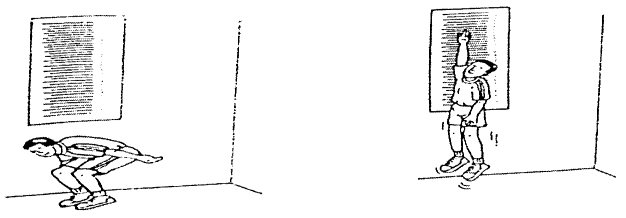

Gambar 1.Tes Loncat Tegak (Vertical Jump)

Sumber: (Afridawati, 2013)

Kecepatan (speed) diukur dengan lari sprint 30 meter, bertujuan mengetahui kecepatan lari.

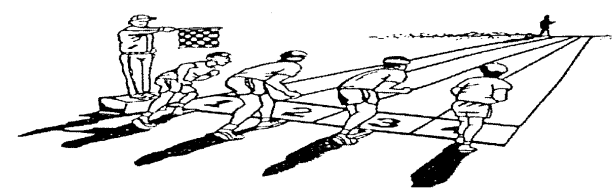

Gambar 2. Lari Sprint $30 \mathrm{~m}$ Sumber: (Afridawati, 2013)

Kelincahan (agility) diukur dengan lari bolak-balik (4x10 m), tujuannya untuk mengetahui kelincahan testee dalam mengubah arah. 


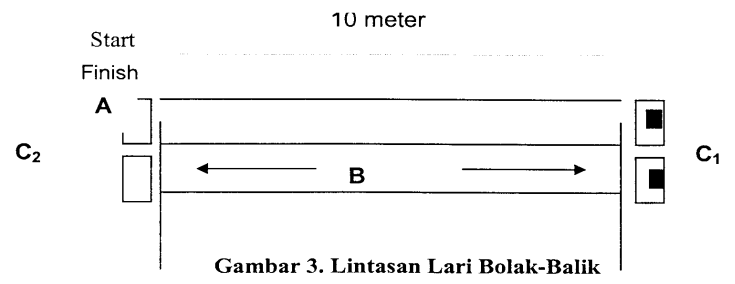

Sumber: (Afridawati, 2013)

Daya tahan otot (muscle endurance) diukur dengan sit up selama 30 detik agar bisa mengukur ketahanan otot pada perut.

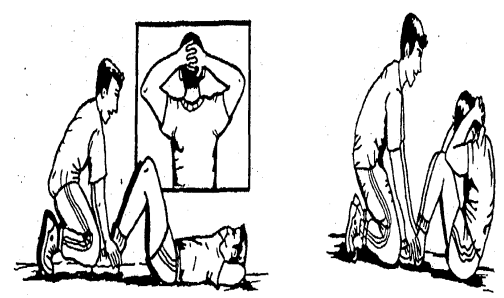

Gambar 4. Tes Baring-Duduk (sit up)

Sumber: (Afridawati, 2013)

Teknik Analisis Data

Analisis datanya menggunakan Statistik deskriptif bertujuan untuk mengetahui gambaran secara nyata sesuai dengan fakta di lapangan. Dalam hal ini peneliti mencoba mendeskripsikan mengenai situasi dan kejadian tertentu. Dalam penelitian ini, peneliti tidak perlu mencari atau menerangkan tentang korelasional, mengajukan ataupun menguji hipotesis. Pengolahan data penelitian hanya menggunakan statistik deskriptif. (Suwirman, 2011).

Langkah untuk mengklasifikasikan sebagai berikut: a) untuk butir tes menggunakan satuan detik, b) tes lompat tegak sentimeter $(\mathrm{cm}), \mathrm{c})$ tes yang berbaring selama 30 detik dalam satuan numerik, d) pengukuran berat dengan kilogram (kg) dan tinggi melalui sentimeter $(\mathrm{cm})$. Selain itu, hasilnya disesuaikan berdasarkan spesifikasi yang sudah distandarkan, seperti tabel berikut 
18 | Arisman ${ }^{1}$, Roby Agun Guntara ${ }^{2}$

The Research of Students' Motor Ability in Archery Extracurricular

Tabel 2. Nilai Tes Motorik Usia 10-12 Tahun

\begin{tabular}{ccccc}
\hline Nilai & $\begin{array}{c}\text { Lari Cepat } 30 \\
\text { Meter }\end{array}$ & $\begin{array}{c}\text { Baring Duduk } \\
\text { 30 Detik }\end{array}$ & $\begin{array}{c}\text { Lari Bolak-Balik } \\
\text { 4x10 Meter }\end{array}$ & Loncat Tegak \\
\hline 5 & $3.58-3.91$ & 23 ke atas & Ke atas 12.10 & 46 ke atas \\
4 & $3.92-4.34$ & $18-22$ & $12.11-13.53$ & $38-45$ \\
3 & $4.35-4.72$ & $12-17$ & $13.54-14-96$ & $31-37$ \\
2 & $4.73-5.11$ & $4-11$ & $14.97-16.39$ & $24-30$ \\
1 & $5.12-5.20$ & $0-3$ & 16.40 ke bawah & 23 ke bawah \\
\hline
\end{tabular}

Sumber: (Depdiknas, 2006)

kemudian data yang sudah terkumpul selanjutnya dianalisis dengan memakai rumus berikut ini:

$$
\begin{array}{|l|l}
\hline \mathrm{P}=\mathrm{F} / \mathrm{N} \times 100 \% & \text { Keterangan: } \\
& \text { P: Persentase } \\
& \text { F: Frekuensi } \\
& \text { N: banyaknya Responden } \\
& \text { Sumber (Yusuf, 2005) }
\end{array}
$$

\section{HASIL DAN PEMBAHASAN}

\section{Hasil Penelitian}

Deskripsi data hasil tes kemampuan motorik secara umum dapat digambarkan sebagai berikut:

Tabel 3. Deskripsi Data Penelitian

\begin{tabular}{llllll}
\hline Variabel & $\mathrm{N}$ & Mean & Stdev & Min & $\max$ \\
\hline Kemampuan Motorik & 30 & 8,50 & 3,25 & 6 & 14 \\
\hline
\end{tabular}

Analisis deskriptif kemampuan motorik dari 30 orang responden penelitian, diperoleh rata-rata hitung $($ mean $)=8.50$, standar deviasi $=3.25$, nilai minimum $=6$ dan maksimum $=14$. Selanjutnya dalam deskripsi ini disajikan distribusi kemampuan motorik sesuai norma tes kemampuan motorik.

Tabel 4. Norma Tes Kemampuan Motorik Putra

\begin{tabular}{ccc}
\hline No & Jumlah Nilai & Kategori \\
\hline 1 & $>10$ & (Baik Sekali) \\
2 & $9-10$ & (Baik) \\
3 & $7-8$ & (Sedang) \\
4 & $5-6$ & (Kurang) \\
5 & $0-4$ & (Kurang Sekali) \\
\hline \multicolumn{3}{c}{ Sumber: Depdiknas (2006) }
\end{tabular}


Berdasarkan rentang nilai diatas dapat dijelaskan sebaran distribusi frekuensi data penelitian menurut masing-masing tingkat klasifikasi. Detailnya ditunjukkan pada tabel berikut:

\begin{tabular}{ccccc}
\multicolumn{5}{c}{ Tabel 5. Frekuensi Kemampuan Motorik } \\
\hline No & Klasifikasi & Nilai & Fa & Fr \\
\hline 1 & Baik Sekali & $>10$ & 7 & 23.33 \\
2 & Baik & $9-10$ & 9 & 30.00 \\
3 & Sedang & $7-8$ & 12 & 40.00 \\
4 & Kurang & $5-6$ & 2 & 6.67 \\
5 & Kurang Sekali & $0-4$ & 0 & 0.00 \\
& Jumlah & & 30 & 100 \\
\hline
\end{tabular}

Untuk lebih jelasnya dapat digambarkan pada histogram berikut :

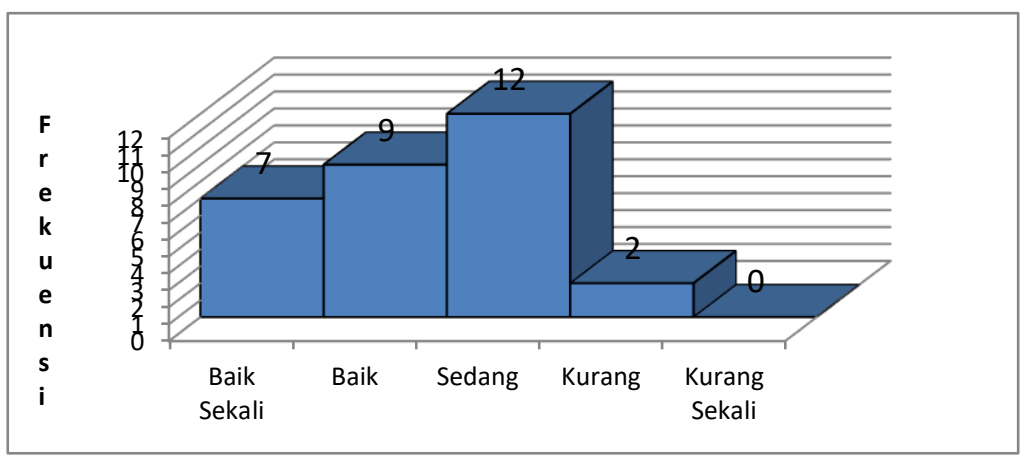

Gambar 5. Histogram Frekuensi Kemampuan Motorik

\section{Pembahasan}

(Trianto, 2007) mengatakan "Pembelajaran adalah proses interaksi antara guru dan siswa dengan menggunakan berbagai sumber belajar sebagai bahan pembelajaran di dalam dan diluar kelas. Pembelajaran pada hakikatnya merupakan upaya sadar yang dilakukan oleh guru untuk mengajar siswa (membimbing siswa berinteraksi dengan sumber belajar lain) guna mencapai tujuan yang diinginkan”. Kemudian secara spesifik pembelajaran Pendidikan Dasar di sekolah menurut (Winarmo, 2006) menjelaskan bahwa :

"Sekolah Dasar adalah salah satu jenis jenjang pendidikan yang formal setingkat lebih tinggi dari Taman Kanak-kanak. Sekolah Dasar pada hakekatnya memiliki tujuan mendidik dan membina anak-anak bangsa dalam berbagai disiplin ilmu pengetahuan, keterampilan, kemampuan, dan nilai-nilai kemanusiaan. Sehingga untuk mencapai tujuan tersebut diperlukan 
suatu rencana pendidikan yang matang yang teroganisir secara baik dalam pelaksanaannya. Agar pendidikan itu mempunyai nilai tambah masyarakat maupun peserta didik itu sendiri".

Hal ini searah dengan yang dikemukakan (Sukintaka, 2004), bahwa "pendidikan jasmani bertujuan untuk mengembangkan aspek organik, motorik, intlektual, dan emosional". Proses belajar mengajar khususnya dalam (penjasorkes) diperlukan tingkat motorik yang baik agar bisa memperoleh hasil belajar yang maksimal, sebaliknya bila kemampuan motoriknya rendah maka siswa akan kesulitan dalam mengembangkan bakat dalam olahraga nantinya. Hal ini bisa menimbulkan kekwatiran untuk masa depan Indonesia dalam bidang Olahraga. karena untuk mendapatkan atlet yang bagus harus ada pembibitan dan pembinaan sejak usia dini salahsatunya melalui gerak multirateral. Sisi lainnya kemampuan motorik yang rendah bisa juga menimbulkan hasil belajar yang buruk. Mengingat pentingnya kemampuan motorik bagi setiap siswa, hal yang perlu diajarkan seorang guru penjas dalam mengajarkan aktifitas fisik disekolah adalah dengan membuat kreatifitas kegiatan untuk menunjang fisiknya dalam bergerak agar lebih leluasa dan fleksibel secara teratur.

Lebih lanjut (Khomsin, 2010) mengemukakan "Penjasorkes merupakan media yang mendorong pertumbuhan fisik, perkembangan mental, keterampilan motorik, pengetahuan dan penalaran, apresiasi nilai (sikap, semangat, emosi, sportivitas, spiritualitas, masyarakat) dan pengembangan gaya hidup sehat untuk merangsang tumbuh kembang". Pada penelitian sebelumnya oleh (Iswantiningtyas, 2015). Terdapat hasil dari Kemampuan Motorik Kasar Anak Usia Dini Melalui Permainan Tradisional Gobak Sodor, penelitian selanjutnya dari (Bagus, 2019) juga ditemukan hasil dari Kemampuan Motorik Siswa pada Ekstrakurikuler Hockey SD. Merujuk hasil kedua penelitian di atas maka dalam hal ini perlu disempurnakan dan dikuatkan dengan hasil pengukuran tes kemampuan motorik siswa SD harapan Indonesia yang berjumlah 30 responden, diperoleh hasil berdasarkan tingkat klasifikasi sebagai berikut: kategori "baik sekali" dengan jumlah 7 orang atau 23.33\%, kategori "baik" ada 9 orang atau $30 \%$, kategori "sedang" 12 orang atau $40 \%$, kategori "kurang" 2 
orang atau $6.67 \%$, sedangkan kategori "kurang sekali" tidak ada. Artinya sesuai dengan rata-rata kemampuan motorik siswa SD Harapan Indonesia berada pada kategori "Sedang".

Usia anak-anak biasanya ada berbagai pengalaman olahraga. Pengalaman tersebut mereka dapatkan dari berbagai olahraga yang mereka lakukan dalam kesehariannya. Seperti berjalan, berlari, melompat, melempar, memanjat, berguling, dll. Namun gerakan-gerakan yang mereka lakukan belum terarah dalam olahraga tertentu, mereka memiliki pengalaman olahraga, yang akan membantu meningkatkan penguasaan keterampilan olahraga (Rahayu, 2019).

Pembelajaran dan pengembangan keterampilan motorik anak di sekolah dasar harus dikelola dengan baik, karena pada usia tersebut merupakan tahapan yang sangat menentukan dalam pengembangan keterampilan motorik tertentu dalam sehari. Perkembangan keterampilan motorik sangat bergantung pada dua faktor pertumbuhan dan perkembangan. Kedua faktor tersebut harus tetap didukung dengan olahraga teratur sesuai kematangan anak dan pemberian pola makan yang baik.

Pertumbuhan yang dimaksud disini adalah perubahan jumlah atau kuantitas organ tubuh yang diukur dengan satuan $(\mathrm{cm})$ misalnya tinggi badan dll, berat badan dengan satuan $(\mathrm{kg})$. Sedangkan perkembangan merupakan proses perubahan pola pikir serta kematangan psikis sehingga semuanya saling membantu dalam meningkatkan kemampuan motoriknya. (Gusril, 2008) menjelaskan bahwa "Unsurunsur yang termasuk dalam keterampilan motorik yakni kekuatan, koordinasi, kecepatan, keseimbangan dan ketangkasan yang dikembangkan sepenuhnya melalui program latihan".

Kekuatan merupakan kondisi otot agar bisa menghasilkan energi dalam berkontraksi. Kekuatan pada otot diharuskan dimiliki anak, apabila tidak ada maka anak tidak akan bisa melakukan aktifitas fisik seperti bermain, memanjat, melempar, bergantung serta mendorong. (Waharsono dan Sajono, 2002) menunjukkan:

"Selama masa kanak-kanak, jaringan otot berkembang pesat. Kekuatan anak perempuan meningkat paling cepat antara usia 9 dan 10 tahun, sedangkan kekuatan anak laki-laki meningkat paling tinggi pada usia 11 
hingga 12 tahun. Ini menambahkan bahwa anak laki-laki berusia antara 6 dan 11 tahun. Kekuatan dua kali lipat".

Koordinasi merupakan kemampuan dalam menyatukan / memisahkan suatu gerak yang kompleks. Gerakan yang terkoordinasi meliputi penyempurnaan otot dan sistem saraf. Contoh: Seorang anak harus mengoordinasikan semua anggota badan yang terlibat saat melempar bola. Jika anak dapat bergerak secara berurutan dengan bebas, mudah dan lancar, serta ritme geraknya terkontrol dengan baik, maka koordinasi geraknya akan baik (Mudzakir, 2020)

Kecepatan bertindak dengan kemampuan yang berdasarkan ketentuan pada saat tertentu. Misalnya: berapa detik yang ditempuh siswa dalam melakukan lari dari jarak yang sudah ditentukan. Semakin jauh jarak yang ditempuh, maka semakin tinggi kecepatan yang harus dimiliki. Keseimbangan juga menjadi muatan penting bagi siswa untuk menjaga berbagai posisi tubuh. Kelincahan juga memiliki peran yang cukup andil bagi siswa dalam saat berpindah dari satu titik ke titik lainnya, ubah arah dan posisi tubuh dengan cepat dan tepat waktu. Misal: semakin cepat siswa melakukan lari zig-zag, semakin tinggi juga kelincahan yang dimiliki. Semua elemen keterampilan motorik siswa dapat dikembangkan melalui pembelajaran fisik dan partisipasi dalam aktivitas semua anggota tubuh.

Semakin banyak siswa mengikuti kegiatan olahraga, maka semakin banyak pula unsur keterampilan olahraga yang dilatihkan. Pengalaman ini akan disimpan dalam memori untuk penggunaan di masa mendatang. Melalui banyaknya pengalaman olahraga yang dilakukan oleh para siswa, tentunya akan meningkatkan kematangan mereka yang sempurna untuk tumbuh kembang. Perkembangan dalam belajar ada fase dimana menggambarkan keadaan atau penguasaan dalam berolahraga, terutama olahraga ketrampilan saat memanah. Kemampuan seseorang untuk menguasai berbagai keterampilan tentu harus ditunjang dengan berbagai variasi latihan-latihan gerak. Anak-anak biasanya memiliki berbagai pengalaman olahraga. Mereka akan mendapatkan pengalaman olahraga ini dari berbagai cabang olahraga dalam kehidupan sehari-hari.

Tahapan motorik siswa kelas V dan VI (umur 10-12 tahun) pemula menurut (Sukintaka, 2004) yakni: 1) aquatik, 2) permainan dan olahraga, 3)aktifitas ritmik, 4) 
aktifitas pengembangan, 5) tes terhadap diri sendiri”. Menurut (Kiram, 2005)““ keterampilan motorik itu bervariasi, hal tersebut bergantung pada kondisi dan keterampilan koordinasi, perbedaan usia, pengalaman olahraga, jenis kelamin, frekuensi latihan, perbedaan tujuan, dan motivasi belajar keterampilan kognitif". Dalam hal ini guru pendidikan jasmani sekaligus sebagai pelatih ektrakurikuler disekolah perlu memahami setiap ciri-ciri koordinasi gerakan dalam penguasaan keterampilan motorik dalam olahraga pada usia anak-anak.

\section{SIMPULAN}

Berdasarkan kepada hasil yang diperoleh dari analisis dan pembahasan yang telah diuraikan. Maka, dapat ditarik kesimpulan bahwasanya Tingkat kemampuan motorik siswa SD Harapan Indonesia sesuai dengan rata-rata hasil yang diperoleh dapat dikategorikan "Sedang”. Maka bisa dikatakan, kemampuan motorik merupakan kualitas individu yang dimiliki seseorang dalam melakukan suatu kesanggupan gerakan sebagai pondasi keberhasilan pencapaian keterampilan gerak.

\section{DAFTAR PUSTAKA}

Afridawati. (2013). Evaluasi, Tes, dan Pengukuran Olahraga. RD Multicpta.

Awalia, F. S., \& Prasetio, Y. (2015). Pengembangan Busur dari Pralon Untuk Pembelajaran. Jurnal Pendidikan Jasmani Indonesia , 88-95.

A. Muri, Yusuf. (2005). Metodologi Penelitian. Padang: UNP Press.

Arikunto, Suharsimi. (2002). Prosedur Penelitian. Jakarta: PT Rineka Cipta.

Bagus Subekti, A. J. I. (2019). Profil Kemampuan Motorik Siswa Peserta Ekstrakurikuler Hockey Sd Negeri Wonokasian 1 Wonoayu Sidoarjo. Jurnal Pendidikan Olahraga dan Kesehatan, 7(3).

Depdiknas. (2006). Kurikulum Tingkat Satuan Pendidikan. Jakarta.

Gusril. (2008). Model Pengembangan Motorik Siswa Pemula. Padang: FIKUniversitas Negeri Padang.

Iswantiningtyas, V., \& Wijaya, I. P. (2015). Meningkatkan Kemampuan Motorik Kasar Anak Usia Dini Melalui Permainan Tradisional Gobak Sodor. PINUS: Jurnal Penelitian Inovasi Pembelajaran, 1(2).

Khomsin. (2010). Penjaskes Sebagai Media Pembentukan Karir.Makalah Seminar Nasional Semarang FIK: UNNES.

Kiram, Yanuar. (2005). Belajar Motorik. Padang: FIK Universitas Negeri Padang.

Lestari, R. Y. (2016). Peran Kegiatan Ektrakurikuler dalam Mengembangkan Watak Kewarganegaraan. Untirta Civic Education Journal , 136-152. 
Magil, Richard. (1980). Motor Learning Concepts Application. Dubuque: IOWA, C. Brown. Company Publisher.

Mudzakir, D. O. (2020). Pengaruh Permainan Olahraga Tradisional Terhadap Motivasi Belajar Dalam Pembelajaran Penjas Kelas V Sekolah Dasar Negeri Dadap 2 Indramayu. Jurnal Maenpo: Jurnal Pendidikan Jasmani Kesehatan dan Rekreasi, 10(1), 44-49.

Rahayu, E. T. (2019). Meningkatkan Waktu Aktif Belajar Siswa Sekolah Dasar Melalui Pemanfaatan Media Pembelajaran Pendidikan Jasmani. Jurnal Maenpo, 9(2), 83-89.

Sukintaka. (2004). Teori Pendidikan Jasmani: Filosofi Pembelajaran Dan Masa Depan. Bandung: Nuansa.

Suwirman. (2011). Metodologi Penelitian. Padang: FIK-Universitas Negeri Padang.

Trianto. (2007). Model Pembelajaran terpadu dalam Teori dan Praktek. Tangerang: Prestasi Pustaka Publisher.

Waharsono dan Sajono. (2002). Buku II Perkembangan dan Belajar Gerak, Biomekanika, Kondisi Fisik Anak-Anak Pemula. Jakarta: Depdiknas.

Winarmo. (2006). Perspektif Pendidikan Jasmani dan Olahraga. Malang : Universitas Malang 